\title{
Regime Change and the Attempted Rehabilitation of Self: Ferenc Fodor and the Production of Communist Geography, 1948-1962
}

\section{Steven Jobbitt}

\begin{abstract}
The communist takeover in Hungary after World War II presented obvious challenges, hardships, and even dangers for the conservative-nationalist scholars who were part of the intellectual elite of the interwar period. Marginalized within the new sociopolitical order that emerged after the communist consolidation of power in 1948-49, conservative-nationalist intellectuals who were not completely silenced by the communists either retreated from public life entirely, or else found themselves having to struggle to remain relevant within the state-socialist system then under construction. Though limited in what they could publish, and relegated to minor and often precarious positions within the scholarly community, former conservative-nationalist scholars were nevertheless granted limited spaces within which they could produce relevant and even important scholarship, and in so doing could also "reinvent" themselves - if in many cases only partially and perhaps opportunistically — as public intellectuals. Focusing on the life and work of Ferenc Fodor between 1948 and his death in 1962, this article explores the concrete ways that a once-prominent geographer of the interwar period continued to contribute to geographical knowledge production under communism, and how he used this scholarly work as leverage in his attempts to partially rehabilitate himself in the early communist period.
\end{abstract}

Keywords: Communism, Hungary, Geographical Knowledge Production, Socio-Political Marginalization, Scholarly Rehabilitation

Biography: Steven Jobbitt is assistant professor of modern East European history at Lakehead University in Thunder Bay, Ontario. He is technical editor of Hungarian Cultural Studies, and is on the editorial board of Földrajzi Közlemények ['Geographical Review']. His current research focuses on Hungarian imperialism in the Balkans at the beginning of the 20th century, and on the history of the radical right in Hungary since 1989.

${ }^{1}$ An earlier version of this article was published in Földrajz és földtudomány az Eötvös Collegiumban ['Geography and Earth Sciences at the Eötvös Collegium’]. Ed. Róbert Győri. Budapest: Eötvös Collegium, 2014: $195-213$. Reprinted with permission. 
Jobbitt, Steven. "Regime Change and the Attempted Rehabilitation of Self: Ferenc Fodor and the Production of Communist Geography, 1948-1962." Hungarian Cultural Studies. e-Journal of the American Hungarian Educators Association, Volume 8 (2015): http://ahea.pitt.edu DOI: 10.5195/ahea.2015.223

In late December 1948, the Hungarian geographer Ferenc Fodor looked back upon his experiences of the previous year. With the communists engaged in a concerted effort to consolidate their power in Hungary and the rest of east central Europe, and with his personal situation growing ever worse, he reflected on the fate that had befallen him, his family, and the nation at large, writing in his autobiographical record "Életem eseményei" ['Events of My Life'] that:

The year has been incredibly severe for us. Beyond my pension of 988 forints per month, there is nothing, no work, left for me. We barely have enough to pay for our food. At the beginning of the year I was able to give some radio lectures, but the radio was soon taken over by the communists for propagandistic purposes, and they immediately put an end to this. In the fall they shut down the University of Economics [Közgazdasági Egyetem], and so my teaching there also came to an end. We truly suffered great privation. Slowly even our clothing started to fall to pieces. Everybody has taken refuge in themselves. [...] Outside of the family we hardly associate with anyone anymore. In the summer my work in the garden helped distract me from my anxiety and constant brooding, but the winter has been incredibly difficult. We do everything alone as a family. The political infighting continues - everyone is fighting everyone. It is impossible to speak safely with people anymore. At Christmas, they arrested the Primate [Cardinal Mindszenty]. For me, the most serious financial loss of the year came in the spring when they nationalized the Catholic schools. With this the possibility of publishing my primary school atlas also disappeared. The atlas was the last financial refuge left to me for my old age. [...] God be with us in the coming year. It promises to be truly grave (Fodor 1959: 52). ${ }^{2}$

[Az 1948. év nagyon súlyos volt ránk nézve. Már semmi más keresetem sem maradt, mint az összesen 988 frt. havi nyugdijunk, ez éppen csak a betevö falathoz elég. Az év elején még néhány rádió-elöadást tarthattam, de azután a rádió is a kommunista propaganda eszközévé válván, elöadásaim is megszüntek. Az összel feloszlatták a közgazdasági egyetemet, sigy egyetemi tanárságom és elöadásaim is megszüntek. Bizony sokat nélkülözünk. Lassan ruházatunk is lepusztul rólunk. Mindenki befelé önmagába menekü.l [...]. A családon kívül alig érintkezünk már másokkal. A nyár folyamán még a kert gondozása elvon a sok tépelödéstöl, de télen nagyon nehéz az életünk. Mindent egyedül csinálunk Virával. A politikai helyzet bent is, mindenki

\footnotetext{
${ }^{2}$ All translations from the original Hungarian are my own. I would like to thank Róbert Györi for his helpful suggestions and corrections. Any mistakes are mine alone.
} 
Jobbitt, Steven. "Regime Change and the Attempted Rehabilitation of Self: Ferenc Fodor and the Production of Communist Geography, 1948-1962." Hungarian Cultural Studies. e-Journal of the American Hungarian Educators Association, Volume 8 (2015): http://ahea.pitt.edu DOI: 10.5195/ahea.2015.223

harca mindenki ellen folyik. Senkivel sem lehet már nyugodtan beszélni. Karácsonykor a primást letartóztatták. A legsúlyosabb anyagi veszteség az volt rám nézve az elmúlt esztendöben, hogy a tavasszal az összes katolikus iskolákat államositván, az iskolai atlaszom újból való kiadásának lehetöségei is teljesen megszüntek, pedig ez az atlasz volt az utolsó anyagi menedékem öreg napjaimra. [...] Az Úristen legyen velünk az új esztendöben, amely igen súlyosnak igérkezik.]

This year-end summary was very typical of the summaries Fodor wrote between the end of the war and 1959 (the year he stopped writing entries in "Életem eseményei"). Much as the short period leading up to the consolidation of communism in 1948-49 had been, each year that passed seemed to be worse than the year that preceded it. At the end of 1951, for example, Fodor wrote: "the year was one of the saddest and to this point most difficult of our lives. It is truly a dismal situation, with misery and hopelessness everywhere [Az 1951. év egyik legszomorúbb és eddig legnehezebb éve volt életünknek. Sötét helyzet, nyomor és reménytelenség mindenütt]" (Fodor 1959: 55). The following year was even worse. On February 19, 1952, Fodor learned that his house was going to be nationalized (Hajdú 2009: VII). Only three days later he was informed that his modest pension had also been suspended (Fodor, however, petitioned the government about this, and was successful in getting it reinstated in March of the same year). The loss of his house was a particularly devastating blow. Though he and his family were allowed to remain as tenants, they were forced to give up ownership to the state, and were now obliged to pay rent. Both humiliating and deeply maddening, the nationalization of his house only increased the financial burden being shouldered by a family who, in Fodor's eyes at least, was already stretched to the limit.

Equally as damaging to his finances, and also his pride, was his scholarly marginalization. Though he had been cleared by a political screening committee in August 1945, and had even been deemed worthy to lecture at the University of Economics between 1946 and 1948, Fodor did not figure into the communist restructuring of the educational system in the postwar period, and was denied the opportunity to teach or lecture at any level (Györi and Gyuris 2012). Moreover, like everyone else who had received a post-graduate degree prior to the communist takeover, Fodor was essentially stripped of his academic credentials. As a result, Fodor found himself having to apply to the newly-established Tudományos Minösitö Bizottság (Academic Accreditation Committee, TMB), a body set up under the aegis of the Hungarian Academy of Sciences, in order to be granted the title of "doctor of science" (Györi and Gyuris 2012, Hajdú 2006, 2009, see also Péteri 1998). As we shall see below, Fodor's on-going struggle with the TMB was both frustrating and humiliating and, as with his efforts to have his house "denationalized," eventually came to naught.

The impact that this combined social, political, economic, and intellectual marginalization had on Fodor cannot be underestimated. It damaged his reputation, it affected his health, it compromised his relationships with former colleagues, and it wounded his pride. Life on the periphery, in short, seriously disrupted his sense of self, and only served to heighten his 
Jobbitt, Steven. "Regime Change and the Attempted Rehabilitation of Self: Ferenc Fodor and the Production of Communist Geography, 1948-1962." Hungarian Cultural Studies. e-Journal of the American Hungarian Educators Association, Volume 8 (2015): http://ahea.pitt.edu DOI: 10.5195/ahea.2015.223

anxiety over Hungary's problematic present, and questionable future.

And yet, despite the social, political, and cultural marginalization he faced as a conservative-nationalist intellectual, scholarly and professional opportunities nevertheless opened up to him. Indeed, the renegotiation - and ultimately public "re-mapping" —of nation and self which preoccupied Fodor throughout the communist period took place within a complex social, cultural, and political space, one which at once both blocked him while allowing him considerable room to maneuver. Though communism as a political-ideological system sought on one level to eradicate all traces of conservative-nationalist and bourgeois-capitalist hegemony, the system itself nevertheless retained not only the territorial foundations of the nation-state, but also much of its technocratic and bureaucratic infrastructure. This fact alone meant that a number of technocrats, intellectuals, and experts from the old order were recruited into the new. Though they were often compelled to perform menial, technical tasks under the supervision of typically young, poorly-educated, and ill-trained party members, they nevertheless played an important, if obviously marginal, role in the socialist system.

Fodor himself recognized almost immediately the opportunities that were open to him, and though he continued to cling in private to a set of culturally-determined, conservativenationalist values which had sustained him since adolescence (see Fodor 1946, 1954a, Tilkovszky 2001, Hajdú 2006, 2009, Jobbitt 2009, 2011, 2013, and Probáld 2012), he was also willing to capitalize on openings which allowed him to pursue his scholarly interests, even if, on an obvious level, such pursuits required something of an intellectual, and probably even moral, compromise on his part (Hajdú 2009: VIII). Driven by a combination of economic necessity, bourgeois pride, and a complex discursive and performative inertia which dictated that, above all else, he keep researching and writing, Fodor was determined to make the most out of the otherwise limited opportunities that were afforded him.

In fact, despite his social, political, and academic marginalization, Fodor remained remarkably prolific as a public intellectual between 1948 and his death in 1962, publishing no less than thirteen scholarly papers (see for example Fodor 1953b, 1954b, 1955a, 1955b), and a total of five lengthy essays and major monographs (two of them multi-volume works) (Fodor 1953a, 1952-1954, 1954c, 1954-1956, 1957). As Zoltán Hajdú notes, these works were by no means insignificant, and represent an important contribution to the history of Hungarian science and geography (Hajdú 2009: XXXI). In what follows, I look at the possible motivations behind Fodor's communist-era work, and argue that his desperate attempt to remain academically relevant after 1948 was driven as much by pride and his desire to be remembered as it was by a basic need for survival in distressing and ultimately hopeless times. An understanding of Fodor's case, I argue, provides important insight into the complex and often very fluid conditions under which at least some geographical work was produced in Hungary during the communist period. Contributing to a growing body of critical work on Hungarian geography under communism, moreover, (see articles by Márton Czirfusz and Róbert Győri in this issue, for example), this study helps to lay the groundwork for future research not only on the role played by interwar geographers in the spatial re-imagining of postwar Hungary, but also on the relationship between the personal and political dimensions of scholarly production in the communist period. 
Jobbitt, Steven. "Regime Change and the Attempted Rehabilitation of Self: Ferenc Fodor and the Production of Communist Geography, 1948-1962." Hungarian Cultural Studies. e-Journal of the American Hungarian Educators Association, Volume 8 (2015): http://ahea.pitt.edu DOI: 10.5195/ahea.2015.223

\section{Scholarship and Survival: Geographical Work as a Means to Some Very Basic Ends}

For Fodor and his family (and indeed for many Hungarians), the years immediately following the communist takeover in 1948-49 marked a difficult, miserable, and ultimately frightening period. As Hajdú writes, these were Fodor's "nyugdijas nyugtalanság évei" ['uneasy retirement years'] (2006: XXI). Under the leadership of Mátyás Rákosi, the Hungarian Communist Party began implementing a repressive system modeled on the Stalinist example already in place in the Soviet Union. The profound hopelessness and even fear that Fodor had felt in the period of political and economic uncertainty that followed the war now became much more palpable. Watching as the communists implemented increasingly oppressive measures against Hungarian society at large, and the middle class in particular, Fodor was again left to wonder what possible future there could be for himself, his loved ones, and the nation.

The distinct sense of a noose being slowly tightened around their collective necks became especially pronounced with the commencement of mass deportations from Budapest at the end of June 1951. In an action that affected between 14,000 and 15,000 people, the communists began seizing houses and apartments throughout the city, more often than not in the more affluent, middle-class districts of the capital (Mark 2005: 967). With their property seized, displaced residents were re-settled, often forcibly, to smaller towns and rural villages, where they were typically forced to engage in manual labor. For an aging Fodor, the thought of re-settlement was deeply upsetting and frightening. Tied as he was to his house, Fodor waited despairingly alongside his family for what he feared was now inevitable. Reflecting on the nearly two months of perpetual dread that they lived through in the summer of 1951, Fodor wrote:

End of June. The deportations from the capital begin. So many of my friends are taken away in the most inhuman circumstances imaginable. Every day at dawn we watch with our hearts beating, waiting to see whether or not a police car will pull up in front of our house to take us away, too. This daily worry continues uninterrupted until the middle of August (1959: $54)$.

[Jún. végén elkezdödtek a fóvárosból való kitelepitések. Nagyon sok barátomat elvitték a legembertelenebb körülmények között. Minden hajnalban mi is szivvdobogva figyeltük, hogy nem áll-e meg mi elöttünk is a kitelepitési parancsot kézbesitö rendörségi autó. Ez a minden hajnali remegés augusztus közepéig tartott egyfolytában.]

To this he added: "July-August. Difficult times. We go nowhere, and simply wait to be resettled. Our health and nerves deteriorate completely" [Júl-aug. Nehéz idök. Sehol sem voltunk, a kitelepitést vártuk, egészen leromlott egészségünk és idegzetünk] (1959: 54).

Though their house would later be nationalized by the state, in the end Fodor and his family were not affected by the re-settlement program. However, despite his family's relative "luck," life under the Rákosi regime was by no means easy for him or his family. Like all other 
Jobbitt, Steven. "Regime Change and the Attempted Rehabilitation of Self: Ferenc Fodor and the Production of Communist Geography, 1948-1962." Hungarian Cultural Studies. e-Journal of the American Hungarian Educators Association, Volume 8 (2015): http://ahea.pitt.edu DOI: 10.5195/ahea.2015.223

Hungarians - with, of course, the exception of certain high level Communist Party members (Valuch 2000: 252) - Fodor and his family suffered heavily under the austerity measures imposed in the early 1950s. His small pension, one which was often not paid out to him in full, and which was even briefly suspended, was woefully inadequate, at least by Fodor's standards, and did little to compensate for the impoverished conditions that he, his wife, and his daughter's young family were forced to endure. The nationalization of his house in February 1952, in turn, came as an even more serious blow for Fodor. So much of his own labor and identity as a conservative, middle-class nationalist was tied up in his house, a structure that served as much as a symbol of his socio-cultural position within Hungarian society as it did an extension of himself. Forced to pay rent for a building which represented his life's work, and which he and his wife had once owned outright, was not only costly, but also fundamentally degrading (Fodor F.-né 1963: 32).

Falling back on the only marketable skills he really had, Fodor immersed himself in scholarly research, hoping to find a place for his work within the newly emerging socialist order. As early as November 1950, in fact, Fodor began working in the map collection of the National Museum with the aim of collecting primary source material for a book on the history of Hungarian cartography. Though it is not entirely certain what made Fodor believe that this would be a worthwhile project in the eyes of the communists, he was evidently confident, or at least hopeful, that he would be able to find a publisher for it. Fodor busied himself throughout the first half of 1951 with his research and writing, finishing an initial draft of the voluminous manuscript in early July. On July 11, he submitted the manuscript to the Honvéd Térképészeti Intézet (the Hungarian Home Army's Institute of Cartography), which at some point earlier in the year had agreed to publish it. Receiving his first set of revisions on December 23, 1951, Fodor was hopeful that his manuscript would soon see the light of day (1959: 54-55). For reasons not fully explained, however, the first volume would not finally be published until September 1954 (1959: 56, see also Papp-Váry 2013).

Having failed to have his A magyar térképírás ['Hungarian Cartography'] published as quickly as he had initially hoped, Fodor was desperate, and by the beginning of 1952 found it necessary to search more actively for paid work. With his house nationalized, and his very modest pension temporarily suspended, he saw himself as having no other choice but to do so. On February 23, 1952, Fodor took stock of his increasingly distressing situation, writing that: "My grievous tribulations have begun. In my sixty-fifth year we go without food. I look for work at the Geological Institute, the Botanical Museum, and the Geography Research Group, but receive only promises" [Elkezdtem a keserves kálváriát, munka után járni. 65 éves koromban betevö falat nélkül maradtunk. Munkát kerestem a Földtani Intézetnél, a Növénytani Múzeumnál, a Földrajzi Kutatócsoportnál, de csak igéretet kaptam] (1959: 55). Receiving "only promises," Fodor was understandably discouraged. Quite to his surprise, however, he was offered some work by the Földrajzi Kutatócsoport (Geography Research Group) only two weeks later. Entrusted with the job of organizing the Budapest map collection, the work, though largely clerical and unchallenging intellectually, nevertheless provided him with an extra source of income, one that would help ease his financial situation, at least temporarily. 
Jobbitt, Steven. "Regime Change and the Attempted Rehabilitation of Self: Ferenc Fodor and the Production of Communist Geography, 1948-1962." Hungarian Cultural Studies. e-Journal of the American Hungarian Educators Association, Volume 8 (2015): http://ahea.pitt.edu DOI: 10.5195/ahea.2015.223

Fodor finished this job, one that paid him 800 forints a month, on June 14, 1952. ${ }^{3}$ His "hard work," however, had not gone unnoticed, and he was immediately offered a new position with the Müemlékek Bizottsága (Committee for Monuments) to research old maps of Hungarian castles. Paying 200 forints a month less than his first job, his work here came to an end on January 15, 1953. This marked the beginning of a few lean months for Fodor and his family. Out of a job, and with no immediate prospects, Fodor again turned to independent research, encouraged, no doubt, by the recent publication of an article he had written on the Hungarian hydrological engineer József Beszédes in the December 1952 edition of the journal Vizügyi Közlemények ['Water Management Bulletin'], for which he was paid 400 forints (Fodor 1959: 55). Taken from a much broader project on the history of Hungarian geography that he had begun collecting material for as early as June 1949 , this biographical essay conformed to the communist search for a usable Hungarian past, one that, at least in this case, played up the technological ingenuity of Hungarian engineers and scientists in the building of a truly modern and progressive industrial state. Though Fodor himself had originally intended his comprehensive history of Hungarian geography to serve as a nationalist rather than socialist study, he was obviously prepared to rework the language and ideological focus in order to get parts of it published under communism. It was, after all, a question of survival (or so he would have us believe).

With his first socialist-era article published, and his work with the Committee for Monuments finished, Fodor began working on a new biography, this time of Antal Balla, an eighteenth-century cartographer and naturalist who was a pivotal figure in the history of modern Hungarian cartography and natural science. Working at his typically accelerated pace, Fodor completed a first draft of the manuscript in the late spring of 1953, and by May 10 had arranged with the Müegyetemi Könyvtár (the Technical University Library) to have it published (Fodor 1953a). The very next day, he was offered more work, this time from the Vízgazdálkodástudományi Kutatóintézet (Hydrological Engineering Research Institute). Acknowledging Fodor's expertise in the field, the institute employed him to track down and catalogue previously unpublished Hungarian hydrological maps.

Despite the fact that he was paid a "meager" 480 forints a month, his new job-one which would last until January 1955 - marked the beginning of a veritable flood of work and publications over the next three years (Fodor 1959: 56-57). Benefiting from the post-Stalinist

${ }^{3}$ Despite Fodor's complaints of economic hardship, his pension of roughly 800 forints a month, supplemented here by a temporary monthly salary of 800 forints, was actually a tidy sum, especially when we take into consideration that his daughter and son-in-law (who lived with him) were also contributing to the household income, and that his wife Vira, as a retired school teacher, was quite likely also collecting a pension. The rent that he would be forced to pay once the house was nationalized early in 1952 amounted to roughly 200 forints a month. His professed poverty, therefore, must be seen in terms relative to his bourgeois expectations. Indeed, Fodor himself notes on at least a few occasions in "Életem eseményei" that he and his family were better off than most under communism. 
Jobbitt, Steven. "Regime Change and the Attempted Rehabilitation of Self: Ferenc Fodor and the Production of Communist Geography, 1948-1962." Hungarian Cultural Studies. e-Journal of the American Hungarian Educators Association, Volume 8 (2015): http://ahea.pitt.edu DOI: 10.5195/ahea.2015.223

political changes that took place in Hungary in the middle of 1953, Fodor wasted no time in capitalizing on the new opportunities that opened up to him and other so-called "creative intellectuals." At about the same time as his lengthy essay on the life and technical work of Antal Balla was published (for which he received a payment of 2,400 forints), Fodor began collecting material for a history of the Institutum Geometricum in Budapest, an institution established in the late eighteenth century that was one of the historical precursors of the Technical University of Budapest. Submitted to the Budapesti Müszaki Egyetem Központi Könyvtár on March 20, 1954, Fodor's study was published the following year under the title Az Institutum Geometricum. Az Egyetem Bölcsészeti Karán 1782-töl 1850-ig fennállott mérnöki intézet ['The Institutum Geometricum: The Engineering Institute of the Faculty of Science at the University, 1782-1850'] (Fodor 1954c).

Between the submission of his historical study on the Institutum Geometricum in the spring of 1954, and its eventual publication in 1955, Fodor also saw the first volumes of two separate multi-volume projects published. On July 20, 1954, the first volume of his three-volume catalogue of hydrological maps was released, while on September 29 of the same year the first of three volumes on the history of Hungarian cartography was finally published. This second was undoubtedly the more satisfying of the two, at least financially. Though he had written in the introduction that his study of Hungarian map-making would not only fill "a gaping hole" in the history of Hungarian science and technology, but would also contribute significantly to the work of building socialism in Hungary (Fodor 1952-1954), Fodor could not conceal in his private papers the obvious glee he felt over the 16,000 forints he received for his work. Though his study had ostensibly been written to help the socialist state reach its utopian goals, for Fodor the payment itself was perhaps the most important consideration, in large part because it provided him with an opportunity to buy new clothes for his entire family. As he would write upon receiving the money on November 24,1954 , "we have already begun the shopping" [elkezdtük a bevásárlást] (1959: 56-57, Jobbitt 2013: 390).

The writing and research did not stop there. Somewhere between the shopping and his on-going work for the Vízgazdálkodás-tudományi Kutatóintézet, Fodor found time to write yet another lengthy monograph, this time on the history of hydrological engineering in the Tisza Valley during the eighteenth and nineteenth centuries. Completing a draft of the study in early December 1954, Fodor submitted a version of it to the Academy of Sciences to be considered for their yearly essay competition. On March 10, 1955, it was announced that he had won first prize for engineering history, and that he would be awarded 5,000 forints for his efforts. Encouraged by his wife, Vira, that he needed to take a break from his work, Fodor used a good part of the money to pay for a vacation for the two of them. Leaving Budapest on August 4, 1955, Fodor and his wife traveled north together to a small town in the Mátra mountains where they planned to spend some time relaxing amidst nature. Perhaps ironically, it was here, only two days later, that Fodor suffered a serious stroke, one that temporarily paralyzed his right side, and which would leave him bed-ridden in hospital for nearly two months. Though Fodor had long been suffering from high blood pressure and "a weak heart," this turn of events took him by surprise, and brought him face to face yet again with his own mortality. Taking his last rites in a hospital 
Jobbitt, Steven. "Regime Change and the Attempted Rehabilitation of Self: Ferenc Fodor and the Production of Communist Geography, 1948-1962." Hungarian Cultural Studies. e-Journal of the American Hungarian Educators Association, Volume 8 (2015): http://ahea.pitt.edu DOI: 10.5195/ahea.2015.223

in Salgótarján, Fodor no doubt felt that his days were now very limited indeed (Fodor 1959: 57 58; see also Fodor F-né 1963).

Before long, however, Fodor felt sufficiently recovered from his stroke to return to his work. Having been informed by the Academy of Sciences that, with some revision, his awardwinning study of hydrological engineering in the Tisza Valley would be considered for publication, he was anxious to continue with his research and writing. Released from hospital on September 20, 1955, Fodor spent the very next day in his library working. Still unable to use his right arm, he enlisted Vira's help to take down notes for him. By the middle of November he was well enough to start going to the National Library by himself. This was obviously a great relief for him, especially since he was keen on completing as much work as he could before dying. With an unmistakable sense of urgency, Fodor wrote in December of the same year that "my health is still in an incredibly delicate state, but I can work" [még mindig igen gyönge állapotban van egészségem, de azért dolgozok] (1959: 58).

Fodor's tenacity once again paid off. Though the return of a hardline communist government at the end of 1955, followed by the revolutionary events of 1956, put a temporary hold on Fodor's attempts to have his latest study published, it was finally released to favorable reviews in December 1957. Comprised primarily of biographical sketches of 568 "hitherto nameless" [névtelen] engineers and surveyors who had worked in the Tisza Valley between 1700 and 1867, and supplemented with a detailed if colorless accounting of what they managed to achieve in that time, Fodor's Magyar Vízimérnököknek a Tisza-völgyben a kiegyezés koráig végzett felmérései, vízi munkálatai és azok eredményei ['The Surveying, Hydrological Work, and Achievements of the Hungarian Hydrological Engineers of the Tisza Valley to the 1867 Compromise'] nevertheless presented a rather glorified image of the ingenuity and persistence of regional and municipal engineers who, in spite of indifferent Austrian monarchs and woefully negligent Hungarian aristocratic landowners, initiated a wide range of locally-funded irrigation, river improvement, and flood control projects. It was to the foresight and energy of these men, concluded Fodor, "that a nation of swamps which remained at the end of the Turkish occupation was transformed into a nation of wheat" [hogy a török hódoltság megszüntével a hátrahagyott vízivilágból búzaország lett] (1957: 3). The collective struggle against the forces of ignorance, tyranny, and nature by educated Hungarian men engaged in practical, state-building work was something to be celebrated, while their perseverance, skill, and foresight was a trait worthy of being emulated by Hungary's newly-constituted socialist man. As one of Fodor's reviewer's put it, these "forgotten heroes" of Hungarian history "deserved to have the flag bowed before them" [a munka immár elporladt és nagyrészt elfeledett hösei elött meghajthassuk a zászlót]" (Fodor Fné 1963: 34).

\section{Fodor's Failed Attempts at Full Social and Academic Rehabilitation}

As with his earlier socialist-era geographies, Fodor's Magyar Vízimérnököknek a Tiszavölgyben stands as a testament to the combined scholarly inertia and material need that compelled him to research and publish into the communist period. The niche that he was able to carve out for himself within the new socialist order, and the relative success of his academic 
Jobbitt, Steven. "Regime Change and the Attempted Rehabilitation of Self: Ferenc Fodor and the Production of Communist Geography, 1948-1962." Hungarian Cultural Studies. e-Journal of the American Hungarian Educators Association, Volume 8 (2015): http://ahea.pitt.edu DOI: 10.5195/ahea.2015.223

work, no doubt gave him some personal and professional satisfaction. However, at the same time, the praise that his work garnered in some circles must have rung like so much empty rhetoric. In letters and petitions sent to the TMB, for example, as well as to municipal housing officials in Budapest, Fodor drew repeated attention to a lifetime of scholarly work, and especially to the socialist scholarship that he had produced or was producing under communism. This latter body of work, he was careful to point out, had not only been lauded and even rewarded by the regime, but also was actively contributing to the building of a strong socialist state. His appeals strongly suggest, in fact, that his communist-era scholarship was intended, at least in part, as political leverage to be used as a means of reclaiming his former status as a socially and academically relevant intellectual of some national import. Accompanied by claims that he was a man of the people genuinely devoted to socialist ideals, Fodor underscored the academic and political importance of his socialist work in the hope that it would not only enhance his chances of being reinstated academically, but also would convince municipal authorities to "de-nationalize" his house, and return ownership to him and his family. As he and his wife, Vira, would write in a letter to housing officials in 1957 (one in which he included a list of his socialist-era scholarship): "Every member of the family that lives in the house is a worker [...] And despite being 70 years old, Dr. Ferenc Fodor, a retired university professor, devotes himself tirelessly to raising the cultural level of our socialist-building country" [A házban lakó családtagok valamennyien dolgozó emberek[...] Dr. Fodor Ferenc ny. egyetemi tanár 70 éves idös kora ellenére is minden igyekezetével azon fáradozik, hogy szocializmust épitö országunk kulturális színvonalának emeléséhez hozzájáruljon]. ${ }^{4}$

The notion that he had always been at heart a man of the people dedicated to the building of a truly democratic socialist state ran through this and other petitions during the communist period. In a letter written in November 1950 to the Kislakás-épitési Váltságmegállapitó Bizottság (the committee charged with redistributing apartments), for example, Fodor highlighted his democratic credentials as part of his petition to be relieved of monthly debt payments that the state had recently required him to pay (Fodor had taken out a loan in 1945 in order to repair his house, and the communists were now asking him to pay back 95 forints a month). Noting that both he and his wife were elderly and sick, and that "two broken, old, and sick people" [két megtört, öreg és beteg ember] could not possibly bear these new burdens, Fodor asked that his debt be forgiven, a request that he felt was reasonable given his past service to the state. Stressing that he had worked his entire life, and would gladly work again if only he was able, Fodor pointed to his admittedly brief re-appointment as school district superintendent by Hungary's democratic government in February 1945 as proof of his true political and ideological

\footnotetext{
${ }^{4}$ Magyar Környezetvédelmi és Vízügyi Múzeum Dokumentációs Gyüjtemény ['The Hungarian Environmental and Water Management Museum'] (MKVM-DGy), “Budapest Ábel Jenö u. 31. sz. házával kapcsolatos iratok, 19471959" ['Correspondence Relating to the Ábel Jenő St. 31 House'], letter from Fodor to the XI. Kerïleti Tanács Végrehajtó-bizottság, Budapest, July 9, 1957.
} 
Jobbitt, Steven. "Regime Change and the Attempted Rehabilitation of Self: Ferenc Fodor and the Production of Communist Geography, 1948-1962." Hungarian Cultural Studies. e-Journal of the American Hungarian Educators Association, Volume 8 (2015): http://ahea.pitt.edu DOI: 10.5195/ahea.2015.223

convictions. Anxious to provide further evidence to back up this claim, he referred to the fact that he had been cleared by the political screening committee in August of the same year, noting that "my democratic conduct was backed up by Iván Boldizsár, the present Secretary of State for Foreign Affairs, who provided definitive evidence of this in my favor" [demokratikus magatartásom mellett akkor Boldizsár Iván, jelenlegi külügyi állam titkár tett döntö vallomást $]{ }^{5}$ With such democratic credentials, Fodor felt it would be wrong to be denied a fair hearing in the matter.

Such a conviction that proof of his long-standing "democratic" nature would hold him in good stead with the regime persisted well into the 1950s in spite of the fact that it rarely, if ever, generated a positive response on the part of communist bureaucrats. In an ultimately unsuccessful protest launched a mere four months after the nationalization of his house in February 1952, for instance, Fodor complained about the "illegal" raising of his rent to 2550 forints per annum. Stating that "though I am 65 years old, I am still in the service of the culture of democracy" [65 évem ellenére ugyanis még mindig a demokrácia kultúráját szolgálom], he pointed to the important scholarly work that had been assigned to him by various government agencies. Much of this extensive academic work, he continued, was done at home. Pointing out that the raising of the rent would force him to move to a smaller apartment, he suggested in no uncertain terms that such a move would make his work quite difficult, if not impossible, to carry out. Without an adequate work space and a library, he would be unable to continue with his research and writing, and would be forced to give back the work entrusted to him by various government- sponsored institutions. As he concluded: "This would in no way be in the interest of the culture of democracy" [ez semmiképpen sem lehet a demokrácia kultúrájának érdeke]. ${ }^{6}$

It is worth noting that, in his unpublished autobiographical notes and manuscripts, Fodor himself was reluctant to record and "remember" his desperate, deeply frustrating, and on some level perhaps even degrading attempts to be recognized by the regime. Casting himself in his private papers as a helpless victim wronged by the injustice of an oppressive regime, Fodor made no reference to his active pursuit of either his academic re-accreditation, or the de-nationalization of his house. His own account (or, rather, lack of it) in "Életem eseményei" of his on-going struggle with the TMB is a good example of how he underplayed and thus conveniently "forgot"

\footnotetext{
${ }^{5}$ MKVM-DGy, “Budapest Ábel Jenö u. 31. sz. házával kapcsolatos iratok, 1947-1959” [“Correspondence Relating to the Ábel Jenő St. 31 House, 1947-1959'], letter from Fodor to the Kislakás-épitési Váltságmegállapító Bizottság, Budapest, November 9, 1950.

${ }^{6}$ MKVM-DGy, “Budapest Ábel Jenö u. 31. sz. házával kapcsolatos iratok, 1947-1959” ['Correspondence Relating to the Ábel Jenő St. 31 House'], letter from Fodor to the KIK 17. sz. kirendeltség, Budapest, June 23, 1952. Fodor ended the letter with the following request: "I conclude by asking once more, therefore, that if the increase in rent was a mistake, that it be corrected, and that if it was intentional, that you would be kind enough to lower it" [Újból kérem tehát, hogy amennyiben lakbérem emelése csak tévedés volt, azt helyesbiteni, amennyiben szándékos volt, a régi alaplakbér visszaállitásával számitott összegre mérsékelni szíveskedjenek].
} 
Jobbitt, Steven. "Regime Change and the Attempted Rehabilitation of Self: Ferenc Fodor and the Production of Communist Geography, 1948-1962." Hungarian Cultural Studies. e-Journal of the American Hungarian Educators Association, Volume 8 (2015): http://ahea.pitt.edu DOI: 10.5195/ahea.2015.223

this somewhat opportunistic element of his communist-era work. Despite the fact that he submitted no less than five official applications for academic re-accreditation between 1952 and 1960, Fodor made only one short note of it in his rather comprehensive, chronological overview of his life. Briefly noting that he had received an "invitation" from the TMB in November 1954 to submit a dissertation for review, he suggested, if only implicitly, that it was they who sought him out, and not the other way around (Fodor 1959: 57). ${ }^{7}$ Though this may have been at least partially true in this one particular case, the existing correspondence that documents Fodor's long-standing dealings with the TMB clearly shows that it was Fodor himself who initiated and actively pursued the possibility of reintegrating himself into Hungarian academe.

Fodor, in fact, proved determined, even relentless, in his pursuit of academic reaccreditation. His first application to the TMB was submitted on December 31, 1952, not long after the establishment of the board itself. ${ }^{8}$ After waiting two years without receiving a response, Fodor again applied, this time with the supposed encouragement of Elemér Vadász, a fellow of the Academy of Science and a former colleague. In the covering letter sent as part of his application in November 1954, Fodor wrote:

On December 31, 1952, as a former university professor, I submitted a request for academic re-accreditation. This request was not dealt with, or, at least, I have yet to receive an answer with regards to this. I therefore respectfully submit the three volumes of my work A magyar térképirás ['Hungarian Cartography']. The first volume of this work has recently been published by the Honvéd Térképészeti Intézet. I ask that this be considered as my dissertation, and that it be deemed worthy enough to be defended and accepted. ${ }^{9}$

[1952 dec. 31-én mint volt egyetemi ny. rk. tanár benyújtottam kérésemet tudományos minösités céljából. Akkor ez nem nyert elintézést, illetve arra

\footnotetext{
${ }^{7}$ In letters written in 1956 and 1960, Fodor indicated that it was Elemér Vadász who had invited him to apply to the TMB. See Magyar Tudományos Akadémia Könyvtár Kézirattár ['Hungarian Academy of Sciences Library Manuscript Collection'] (MTAKK), Ms 5271/111, Ferenc Fodor to Béla Bulla, Budapest, July 10, 1956; and Magyar Tudományos Akadémia Levéltár ['Hungarian Academy of Sciences Archive'] (MTAL), file no. 843/1 "Fodor Ferenc," Ferenc Fodor to the TMB, Budapest, February 22, 1960. See also Hajdú 2009.

${ }^{8}$ For brief references to his application in 1952, see MTAL, file no. 843/1 "Fodor Ferenc," letter from Ferenc Fodor to the directors of the TMB, Budapest, November 18, 1954; and MTAL, file no. 843/1 "Fodor Ferenc," letter from Ferenc Fodor to the TMB, Budapest, February 22, 1960.

${ }^{9}$ MTAL, file no. 843/1 "Fodor Ferenc," letter from Ferenc Fodor to the directors of the TMB, Budapest, November $18,1954$.
} 
Jobbitt, Steven. "Regime Change and the Attempted Rehabilitation of Self: Ferenc Fodor and the Production of Communist Geography, 1948-1962." Hungarian Cultural Studies. e-Journal of the American Hungarian Educators Association, Volume 8 (2015): http://ahea.pitt.edu DOI: 10.5195/ahea.2015.223

eddig választ nem kaptam. Ennélfogva tisztelettel mellékelve "A Magyar térképirás" címü, a Honvéd Térképészet kiadásában megjelent I-III. kötetes müvemet, kérem azt dissertationak tekinteni, a további minösitési eljárás alapjául elfogadni és annak megvédésre utasítani, illetve behívni.]

As it was with his first application, however, Fodor never did receive a letter from the TMB, and it was only much later that he learned from Vadász himself that previously published manuscripts would not be considered by the board. Undeterred, Fodor tried his luck again two years later, this time soliciting the assistance of the geographer and Academician Béla Bulla, a former friend and Eötvös Collegium colleague from the interwar period who had clearly been much more successful than Fodor at integrating himself into the new academic order (on Bulla see Győri and Gyuris 2012, Marosi 2006, Hajdú 2009: XIII). ${ }^{10}$ On July 10, 1956, Fodor wrote to Bulla informing him that he had submitted his application to the TMB along with a new dissertation, a roughly 100-page, type-written manuscript entitled "A magyar földrajzi tudományok múltja Anonymustól Hunfalvy Jánosig" ['The History of Hungarian Geographical Science from Anonymous to János Hunfalvy']. Obviously disappointed with Vadász's inability (or unwillingness) to help two years earlier, Fodor not only wanted to inform Bulla of the nature and contents of his application, but also wished to encourage his continued support by thanking him in advance for his kind assistance in the matter. ${ }^{11}$

Despite whatever efforts Bulla may have made on Fodor's behalf, the application failed. This was followed by yet another unsuccessful application the following year, when Fodor submitted a much longer manuscript on the history of Hungarian geography to be considered as his doctoral dissertation. Yet another application-Fodor's fifth in eight years-was filed three years later, in February 1960. Frustrated with the handling of his case, and worried that he would not see it resolved before his death, Fodor implored the TMB to finally give his application fair consideration, writing:

I, Ferenc Fodor, a former university professor, ask the TMB to be so kind as to consider my application, one I have made many times, for academic reaccreditation. I made my first application at the time of the TMB's

\footnotetext{
${ }^{10}$ For details of Bulla's application for re-accreditation, see MTAL, file no. 917/617, "Bulla Béla.” It is worth noting that, as Bulla's senior, Fodor had on at least one occasion in the past been able to help him in the early stages of his career, securing a position for him at the Eötvös Collegium in Budapest in 1929. See MTAKK, Ms 5271/110, letter from Fodor to Béla Bulla, Budapest, June 7, 1929. See also MTAKK, Ms 5271/109, letter from Fodor to Béla Bulla, Budapest, May 13, 1929.

${ }^{11}$ MTAKK, Ms 5271/111, letter from Fodor to Bulla, Budapest, July 10, 1956. For a copy of the covering letter sent to the TMB, see MTAKK, Ms 5271/112, letter from Fodor to the TMB, Budapest, July 10, 1956.
} 
Jobbitt, Steven. "Regime Change and the Attempted Rehabilitation of Self: Ferenc Fodor and the Production of Communist Geography, 1948-1962." Hungarian Cultural Studies. e-Journal of the American Hungarian Educators Association, Volume 8 (2015): http://ahea.pitt.edu DOI: 10.5195/ahea.2015.223

founding, and did not receive a response. I made my second application in 1954 after being invited to do so by the Academician Elemér Vadász, again without receiving a judgment or answer. I made my third application on July 1, 1956 on the invitation of the Academician Béla Bulla, but likewise did not receive a response. My fourth application was submitted on January 9,1957 , but this too was not deemed worthy of a response. Now I make my fifth application in the hope that, on the basis of a lifetime of highly esteemed scholarship, my application will finally be granted a hearing. I am a seriously ill, 73 year-old man. I am sure that it is understandable why, in the twilight of my life, I should continue to pursue the recognition I feel my scholarly work deserves. I have included an abridged list of my life's work, as well as a copy of "Hungarian Hydrological Engineers of the Tisza Valley," my latest, award-winning work, to be considered as my dissertation. ${ }^{12}$

[Kérem a Tudományos Minösitö Bizottságot, hogy nekem, Fodor Ferenc volt nyilv. egyet. rendkívüli tanárnak az általam már többször kért tudományos minösitést megadni sziveskedjenek. Minösitésemet elöször a Minösitö Bizottság megalakulásakor kértem, azonban választ nem kaptam rá. Másodszor 1954-ben Vadász Elemér akadémikus személyes felhívására kérésemet megismételtem, ismét eredmény és válasz nélkül. Harmadszor 1956. júl. 1-jén Bulla Béla akadémikus felhívására ismételtem meg kérésemet, de választ ugyancsak nem kaptam. Negyedszer 1957. jan. 9-én adtam be kérésemet, de válaszra sem méltattak. Most ötödszörre teszem meg ugyanezt, abban a reményben, hogy indokolt és tudományos munkásságom alapján méltányos kérésem végül meghallgatást nyer. 73 éves súlyos beteg ember vagyok, azt hiszem érthetö, ha életem alkonyán ragaszkodom ezen elismerés megadásához. Mellékelem tudományos munkásságom egy kivonaton jegyzékét, valamint dissertációképen legutolsó akadémiai pályadíjnyertes munkámat, melynek címe: "Magyar vízimérnököknek a Tisza-völgyben a kiegyezés koráig végzett felmérési, vízi munkálatai és azok eredményei."]

Impassioned but ultimately futile, this was to be Fodor's last desperate attempt to settle the question of his academic status. Only four months later he would finally get a reply from the board, though not the one he had long been hoping for. On July 4, 1960, Fodor received a letter

\footnotetext{
${ }^{12}$ MTAL, file no. 843/1 "Fodor Ferenc," letter from Fodor to the TMB, Budapest, February 22, 1960.
} 
Jobbitt, Steven. "Regime Change and the Attempted Rehabilitation of Self: Ferenc Fodor and the Production of Communist Geography, 1948-1962." Hungarian Cultural Studies. e-Journal of the American Hungarian Educators Association, Volume 8 (2015): http://ahea.pitt.edu DOI: 10.5195/ahea.2015.223

stating simply that "the TMB has looked at your application for re-accreditation. We regret to inform you that this cannot be granted. The publication you submitted, by virtue of its [previously published] nature, does not meet the requirements of a doctoral candidate's dissertation" [A Tudományos Minösitö Bizottság foglalkozott minösitési kérelmével. Sajnálattal közöljük, hogy azt nem teljesítheti. A beküldött publikáció-jellegénél fogva-nem felel meg a kandidátusi disszertáció követelményeinek]. Making reference to the much-abbreviated bibliography of his life's work that he sent along with his application, they added: "The Tudományos Minösitö Bizottság is not in the position to grant you special treatment based on your previous work" [eddigi munkássága alapján rendkivüli, kedvezményes minösitési eljárást sem alkalmazhat a Tudományos Minösitö Bizottság]. ${ }^{13}$

\section{Conclusion}

Fodor's relentless attempts to be reaccredited by the TMB suggest that his scholarly output during the communist period was driven as much by pride, and perhaps even a lingering sense of bourgeois entitlement, as it was by the need for basic survival. And yet, no matter how vain and politically naïve the pleas at the end of his life may seem, his desperate need to have his scholarly work recognized by the new regime betrays also a profoundly existential impulse, one which, however self-important it may seem on the surface, no doubt speaks to a broader phenomenon of the modern era. Indeed, as I have argued elsewhere, Fodor lived in constant fear, especially in the last two decades of his life, that he himself would be forgotten by future generations (Jobbitt 2009, 2011, 2013). His attempts to remain academically relevant under communism, therefore, cannot be seen as simple opportunism. Though he openly attempted to leverage his scholarly output in order to enhance his income or his status under communism, his need for scholarly recognition ran parallel with a need that motivated him throughout his twilight years, and that was to be reassured that his life had been somehow meaningful, and that his life's work would survive him, and thus keep his memory alive once he was gone.

Whatever impulses may have motivated him to continue researching and publishing under communism, Fodor's case is a good example of the opportunities that remained open to intellectuals from the interwar period after World War II. In need of the technical and scholarly expertise of academics like Fodor who served the conservative-nationalist state faithfully between the wars, the new cadres that came to power in 1948-49 made use of these scholars in their attempts to build a socialist society. Though reluctant to fully rehabilitate intellectual workers like Fodor, communist state-builders nevertheless made use of these individuals, and obviously benefitted from their desire to remain productive and academically relevant after the

\footnotetext{
${ }^{13}$ MTAL, file no. 843/1 "Fodor Ferenc," letter from Gábor Tolnai, TMB secretary, to Fodor, Budapest, July 4, 1960.
} 
Jobbitt, Steven. "Regime Change and the Attempted Rehabilitation of Self: Ferenc Fodor and the Production of Communist Geography, 1948-1962." Hungarian Cultural Studies. e-Journal of the American Hungarian Educators Association, Volume 8 (2015): http://ahea.pitt.edu DOI: 10.5195/ahea.2015.223

war. The scholarly spaces and opportunities that persisted for former conservative-nationalist intellectuals under communism were not only necessary for the re-imagining and rebuilding of the nation and the state, but also provided a chance for these intellectuals to reinvent themselves. Though the extent to which this reinvention of self was primarily opportunistic may remain an open question in some cases, there can be no doubt that, as far as Fodor is concerned, the remapping of socialist Hungary ran parallel with a more personal project, one which intersected with, and informed, the geographical work he produced up until his death in 1962.

\section{Works Cited}

\section{Archival Sources}

Bulla Béla hagyatéka ['Béla Bulla Collection']. Magyar Tudományos Akadémia Könyvtár Kézirattár ['Hungarian Academy of Sciences Library Manuscript Collection'], Ms. 5271.

Bulla Béla hagyatéka ['Béla Bulla Collection']. Magyar Tudományos Akadémia Levéltár ['Hungarian Academy of Sciences Archive'], file no. 917.

Fodor Ferenc hagyatéka ['Ferenc Fodor Collection']. Magyar Tudományos Akadémia Levéltár ['Hungarian Academy of Sciences Archive'], file no. 843.

Fodor, Ferenc. 1946. "A magyar lét földrajza" ['The Geography of Hungarian Being']. Magyar Tudományos Akadémia Könyvtár Kézirattár ['Hungarian Academy of Sciences Library Manuscript Collection'], Ms. 10739/I. and Ms. 10739/II. . 1954a. "Szatmár földje, Szatmár népe, Szatmár élete" ['The Land, People, and Life of Szatmár']. Magyar Tudományos Akadémia Könyvtár Kézirattár ['Hungarian Academy of Sciences Library Manuscript Collection'], Ms 10.740/1. . 1959. "Életem eseményei" (1887-1959) ['Events of My Life (1887 1959)']. Magyar Környezetvédelmi és Vízügyi Múzeum Dokumentációs Gyüjtemény ['The Hungarian Environmental and Water Management Museum'], H-20/1 28- 97. 1/2. . 1947-1959. "Budapest Ábel Jenő u. 31. sz. házával kapcsolatos iratok, 1947-1959" ['Correspondence Relating to the Ábel Jenő St. 31 House, 1947-1959']. Magyar Környezetvédelmi és Vízügyi Múzeum Dokumentációs Gyüjtemény ['The Hungarian Environmental and Water Management Museum'], H-20/1 28-97. 1/8.

Fodor Ferencné Fenczik Vira. 1963. "Fodor Ferenc geográfus életének főbb eredményei és állomásai" ['The Main Events and Stages of the Geographer Ferenc Fodor's Life']. Magyar Tudományos Akadémia Könyvtár Kézirattár ['Hungarian Academy of Sciences Library Manuscript Collection'], Ms. 10740/78.

\section{Secondary Sources}

Fodor, Ferenc. 1953a. Balla Antal élete és müszaki munkássága. 1739-1815 ['The Life and Technical Works of Antal Balla, 1739-1815']. Budapest: Tankönyvkiadó. . 1953b. "A Szamoshát ösvízrajza" ['The Ancient Hydrography of Szamoshát'] Földrajzi Közlemények ['Geographical Review'] 3-4, 193-204. 
Jobbitt, Steven. "Regime Change and the Attempted Rehabilitation of Self: Ferenc Fodor and the Production of Communist Geography, 1948-1962." Hungarian Cultural Studies. e-Journal of the American Hungarian Educators Association, Volume 8 (2015): http://ahea.pitt.edu DOI: 10.5195/ahea.2015.223

1952-1954. A magyar térképírás I-III ['Hungarian Cartography, volumes IIII']. Budapest: Honvéd Térképészeti Intézet. . 1954b. "Pozsony, Buda, Kolozsvár földrajzi helyzete legrégibb térképeinkben I" ['The Geographical Situation of Pozsony, Buda, and Kolozsvár in Our Oldest Maps (Part I)'] Földméréstani Közlemények ['Geodesy Review'] 6-4: 225-230. 1954c. Az Institutum Geometricum. Az Egyetem Bölcsészeti Karán 1782-töl 1850-ig fennállott mérnöki intézet ['The Institutum Geometricum: The Engineering Institute of the University's Faculty of Arts from 1782 to 1850']. Budapest: Tankönyvkiadó. 1954-1956. A magyarországi kéziratos vízrajzi térképek katalógusa 1867-ig. I-III. kötet ['A Catalogue of Hungarian Hydrological Maps to 1867, volumes I-III']. Budapest: Tankönyvkiadó.

— 1955a. "Magyarország vízrajzi térképezése II. József korában" [‘The Cartography of Hungarian Hydrology in the Era of Joseph II']. Vizzügyi Közlemények ['Hydrology Review'] 3-4: 379-396.

_ 1955b. "Pozsony, Buda, Kolozsvár földrajzi helyzete legrégibb térképeinkben II" ['The Geographical Situation of Pozsony, Buda, and Kolozsvár in Our Oldest Maps (Part II)']. Földméréstani Közlemények ['Geodesy Review'] 1: 45-51.

. 1957. Magyar Vízimérnököknek a Tisza-völgyben a kiegyezés koráig végzett felmérései, vízi munkálatai és azok eredményei ['The Surveying, Hydrological Work, and Achievements of the Hungarian Hydrological Engineers of the Tisza Valley to the 1867 Compromise']. Budapest: Tankönyvkiadó.

Győri, Róbert, and Ferenc Gyuris. 2012. "The Sovietisation of Hungarian Geography, 1945-1960. Mitteilungen der Österreichischen Geographischen Gesellschaft ['Review of the Austrian Geographical Society'] 154: 107-128.

Hajdú, Zoltán. 2006. "Fodor Ferenc, a geográfus" [“The Geographer Ferenc Fodor']. In Ferenc Fodor, A magyar földrajz tudomány története ['The History of Hungarian Geography']. Budapest: MTA FKI: XI-XLII.

. 2009. "Fodor Ferenc: Geográfus történeti és néprajzi érzékenységgel” ['Ferenc Fodor: A Geographer with Historical and Ethnographical Sensitivities']. In Ferenc Fodor, Az elnemsodort falu ['The Village Not Swept Away']. Debrecen: Debreceni Egyetem Néprajzi Tanszék: I-XXXV.

Jobbitt, Steven. 2009. "Remembering Szatmár, Remembering Himself: The Geography of Memory and Identity in Ferenc Fodor's 'Szatmár Földje, Szatmár Népe, Szatmár Élete." Hungarian Studies Review XXXVI, Nos. 1-2: 15-38.

_. 2011. "Memory and Modernity in Fodor's Geographical Work on Hungary." In Comparative Hungarian Cultural Studies. Eds. Steven Tötösy de Zepetnek and Louise O. Vasvári. West Lafayette: Purdue University Press: 59-71. . 2013. "Emlék Szatmárról—emlék Fodor Ferencről. Az emlékezés és az identitás földrajza Fodor Ferenc: 'Szatmár földje, Szatmár népe, Szatmár élete' című müvében” ['Memories of Szatmár-Memories of Ferenc Fodor: Memory and the Geography of 
Identity in 'The Land, People, and Life of Szatmár']. Földrajzi Közlemények ['Geographical Review'] 4: 385-398.

Mark, James. 2005. "Society, Resistance and Revolution: The Budapest Middle Class and the Hungarian Communist State 1948-56." English Historical Review 488: 963-986.

Marosi, Sándor. 2006. "Bulla Béla emlékezete" ['Remembering Béla Bulla']. Földrajzi Közlemények ['Geographical Review'] 3-4: 103-110.

Papp-Váry, Árpád. 2013. “Egy 'elfeledett geográfus' el nem felejtett térképészeti munkájáról" ['On the Unforgettable Cartographical Work of a Forgotten Geographer']. Földrajzi Közlemények ['Geographical Review'] 1: 78-80.

Péteri, György. 1998. Academia and State Socialism: Essays on the Political History of Academic Life in Post-1945 Hungary and East-Central Europe. Boulder, CO: Social Science Monographs.

Probáld, Ferenc. 2012. "Egy elfeledett geográfus lappangó műve: a Magyar lét földrajza" ['The Hidden Work of a Forgotten Geographer: The Geography of Hungarian Being']. Földrajzi Közlemények ['Geographical Review'] 4: 453-458.

Tilkovszky, Loránt. 2001. "Fodor Ferenc és Teleki Pál. A ‘bujdosó könyv’ történetéhez" ['Ferenc Fodor and Pál Teleki: The History of a bujdosó könyv']. In Ferenc Fodor, Teleki Pál. Budapest: Mike és Társa Antikvárium: 503-557.

Valuch, Tibor. 2000. "A Cultural and Social History of Hungary, 1948-1990." In A Cultural History of Hungary in the Nineteenth and Twentieth Centuries. Ed. László Kósa, trans. Tom Wilkinson. Budapest: Osiris Kiadó: 249-349. 